\title{
Оптические и структурные свойства двумерных слоёв кремния, встроенных в диэлектрическую матрицу фторида кальция
}

\author{
В.А. Зиновьев ${ }^{1}$, А.В. Кацюба ${ }^{1}$, В.А. Володин ${ }^{1,2}$, А.Ф. Зиновьева ${ }^{1,2}$, С.Г. Черкова ${ }^{2}$, Ж.В. Смагина ${ }^{2}$, \\ А.В. Двуреченский ${ }^{1,2}$, А.Ю. Крупин ${ }^{3}$, О.М. Бородавченко ${ }^{4}$, В.Д. Живулько ${ }^{4}$, А.В. Мудрый ${ }^{4}$ \\ ${ }^{1}$ Институт физики полупроводников им. А.В. Ржанова СО РАН, Новосибирск, \\ 630090, Лаврентьева, 13 \\ ${ }^{2}$ Новосибирский государственный университет, Новосибирск, 630090, Пирогова, 2 \\ ${ }^{3}$ Новосибирский государственный технический университет, Новосибирск, 630073, К.Маркса, 20 \\ ${ }^{4}$ ГО «НПЦ НАН Беларуси по материаловедению», Минск, Беларусь, 220072, П. Бровки, 19 \\ тел:+7 (913) 333-2519, факс:+7 (913) 333-2466, эл. почта: zinoviev@isp.nsc.ru
}

DOI 10.34077/RCSP2021-95

B настоящее время во всем мире наблюдается повышенный интерес к двумерным материалам на основе кремния и германия [1]. Ожидается, что эти материалы будут иметь электронную структуру с прямой запрещенной зоной, что должно приводить к эффективной люминесценции. Настоящая работа направлена на поиск оптимальных условий для формирования двумерных слоёв $\mathrm{Si}$, встроенных в диэлектрическую матрицу $\mathrm{CaF}_{2}$, а так же на исследование их структурных и оптических свойств. Нами был проведён рост эпитаксиальных структур, содержащих тонкие слои $\mathrm{Si}$, встроенные в диэлектрическую матрицу $\mathrm{CaF}_{2}$. Рост проводился методом молекулярно-лучевой эпитаксии на подложках $\mathrm{Si}(111)$. Исследования морфологии поверхности выращенных структур позволили определить условия роста, благоприятные для формирования двумерных слоёв Si. Методом спектроскопии комбинационного рассеяния света (КРС) были проведены исследования колебательных спектров созданных структур. В спектрах КРС от структур с одним бислоем $\mathrm{Si}$, встроенным в $\mathrm{CaF}_{2}$, обнаружен узкий пик при $418 \mathrm{~cm}^{-1}$, который обусловлен колебаниями $\mathrm{Si}-\mathrm{Si}$ связей в плоскости двумерного слоя $\mathrm{Si}$, интеркалированного в $\mathrm{CaF}_{2}$. Результаты исследований, выполненные для многослойных структур, продемонстрировали, что в выбранных условиях роста с увеличением количества слоёв структуры сохраняется планарность гетерограниц $\mathrm{Si} / \mathrm{CaF}_{2}$, что позволяет наблюдать усиленный суммарный сигнал КРС от 10 двумерных слоёв $\mathrm{Si}$ толщиной в 1 атомный бислой. Исследования методом фотолюминесценции (ФЛ) показали, что в спектрах ФЛ от созданных структур наблюдаются полоса излучения при 680 нм, которая может быть связана с излучательной рекомбинацией носителей заряда в двумерных слоях $\mathrm{Si}$, встроенных в диэлектрическую матрицу. Проведено исследование эффекта гидрогенизации на оптические свойства выращенных структур с двумерными слоями $\mathrm{Si}$, встроенными в диэлектрическую матрицу $\mathrm{CaF}_{2}$. Проведённый анализ спектров ФЛ показал, что обработка в водородной плазме приводит к заметному усилению (почти в 4 раза) интегральной интенсивности сигнала ФЛ от многослойной структуры с двумерными слоями $\mathrm{Si}$ в спектральном диапазоне длин волн от 400 до 800 нм.

Работа выполнена при финансовой поддержке РФФИ (грант № 20-52-00016) и БРФФИ (грант №Ф20Р-092).

\section{Литература}

[1] M. Galbiati, N. Motta, M. De Crescenzi, L. Camilli // Appl. Phys. Rev. 2019. V.6, 041310. 